\title{
A Comparison of Peer Tutoring to Academic Tutoring on At-Risk College Students
}

\author{
Dr. Valeria A. Russ \\ Fayetteville Technical Community College \\ 2201 Hull Road, Fayetteville, NC 28303
}

\begin{abstract}
This study indicates the positive impacts of peer tutoring on at-risk students' academic achievement. The differences between the final grades of at-risk students who received peer tutoring were compared to those who received academic tutors. In 2007, a University in the Southeastern United States began the Academic Enrichment Program (AEP), which is a two-semester program that enrolls students who are considered at-risk. In this study, the participants consisted of 105 college freshmen, 70 males and 35 females, who were conditionally enrolled at the University in the AEP. Each of the participants was assigned to peer tutoring or academic tutoring. Results of a one-way analysis of variance determined there were significant differences in final grades of students who received peer tutoring compared to academic tutoring.
\end{abstract}

Keywords: Academic Enrichment Program (AEP), tutoring, peer tutoring, academic tutoring.

This study examined the differences between the final grades of at-risk students who received peer tutoring to at-risk students who received academic tutoring. At-risk students who received peer tutoring indicated a significant difference in final grades as compared to those who received academic tutoring. These results indicate a positive impact of peer tutoring on at-risk student achievement.

\section{Literature Review}

Tutoring services have been and continue to be an important part of academic support programs designed for students. Tutoring programs are designed for and target at risk students who may drop out of college due to inadequate preparation (Rheinheimer et al., 2012). Tutoring programs were reviewed with specifics to research linking tutoring with academic performance. These studies showed that tutoring programs may have had a positive effect on academic performance in specific courses and may have had a positive impact on students' social environment.

Peer tutoring has various definitions; for example, Kalkowski, (1996) defined peer tutoring as an approach in which one individual instructs another individual on material in which the first individual is an expert. Gisbert and Font, (2008) defined peer tutoring as tutoring that promotes the mastering of interpersonal competencies. Miller (2005) defined peer tutoring as tutoring that involves student helpers assisting in the learning process and helping their peers to learn by teaching. Gaustad (1993) explained that peer tutoring occurs when tutor and tutee are the same age.

Duran and Monereo (2005) defined peer tutoring as a method of cooperative learning based on the creation of pairs of students with an asymmetrical relationship and a single common goal which is known and shared and must be achieved through a relationship framework planned by the teacher. Traditionally, students who struggle in a specific content area would be paired with a higher performing peer to receive instruction (Miller, 2005). Damon and Phelps (1989) define peer tutoring as an approach in which one child instructs another child in material on which the first is an expert and the second is a novice. Peer tutoring is also defined as one who has the same or similar academic background as the tutee where the tutor and tutee are considered at risk and/or underprepared and were conditionally enrolled in their university. Regardless of the definition of peer tutoring, an important question is whether peer tutoring is effective.

According to Maxwell (1990), students feel more relaxed with peers and relate to them in different way than professional helpers. Maxwell further suggests that the closer the tutor and tutee were in grade, the more problem solving the tutee engaged in during the session. In several reviews of peer tutoring programs, researchers found that when students participate in tutoring sessions for reading, improvements in reading occurred for those students.

\section{Method}

Based on the indicated influx and established need for academic support of at-risk students, the current study sought to examine the impact of peer tutoring on final grades of these students. Students who have peer tutoring may have an advantage because students feel more at ease and comfortable with their peers and as such may ask more questions. The research question of this study is as follows: 
Is there a significant difference between the final grade earned in a course the student received tutoring when comparing peer tutoring sessions and academic tutoring sessions? The null hypothesis tested in the study is as follows: There is no relationship between tutoring conditions (peer versus academic) and final grade earned in course of high risk/underprepared students.

\section{Participants}

In 2014, a University in the Southeastern United States began the Academic Enrichment Program (AEP), which is a two-semester program designed to provide help to students who have been identified as underprepared and/or at-risk, using the University admissions criteria. Underprepared and/or at-risk students who were accepted to the University were admitted with the understanding that their participation in the AEP program was a condition of their admission and enrollment in the University. Students enrolled in the AEP program signed a contract detailing the rules and guidelines of their enrollment. Ninety-five AEP student records were used in the study. The participant records include 35 females and 70 males. Of these participants, 45 were African American, 38 were Hispanic/Latino, and 22 were Caucasian.

\section{Procedures}

The academic advisor assigned students to the peer or academic tutoring sessions. The tutoring sessions were held in a classroom that had been designated for the tutoring sessions. The facilitator had access to all technical equipment, such as, PowerPoint, computers, etc. for presentations. The academic tutoring sessions were held in the tutoring center. Spaces had been partitioned to give some degree of privacy during the sessions. Two computers were available for use during the sessions. Tutors had access to instructor manuals for references. Tutors maintained a current log of AEP students who attended tutoring and the name of the course or courses in which they received tutoring. At the conclusion of the tutoring sessions, the researcher was provided with the final grade outcome. This information was analyzed to determine if there was a significant effect of tutoring services on final grade. The tutoring logs and test scores were significant but not high in construct validity.

\section{Data Analysis}

This study used an ex post facto design to analyze the tutoring methods of the independent variable, peer tutoring compared to academic tutoring. An ANOVA was used to measure differences in final grades for peer tutoring and academic tutoring. The final grades are in those courses that the students' received tutoring. The data provided by the Registrar's Office and the Academic Enrichment Program Coordinator included high school GPA scores, SAT, and/or ACT scores and final grades in the course's students received tutoring services.

Data were analyzed using the Statistical Package for the Social Sciences (IBM SPSS) 16.0 computer software program. Descriptive statistics were reported for sample demographics, and the independent, and dependent variables of interest. A one-way ANOVA was used to compare the type of tutoring sessions, such as peer or academic to final grade in the course for which the student received tutoring. The ANOVA was appropriate for this study because it has the potential to produce significant values indicating whether there were significant differences within the comparisons being made.

\section{Results}

A one-way ANOVA was conducted to examine if there was a statistically significant difference in final grades of students who attended peer tutoring compared to those who attended academic tutoring. For peer tutoring, $\mathrm{M}=78.96$, $\mathrm{SD}=12.50, \mathrm{~N}=40$, and academic tutoring, $\mathrm{M}=66.40, \mathrm{SD}=19.34, \mathrm{~N}=55$. The ANOVA revealed a statistically significant difference in the final grades of students who attended peer tutoring compared to those who attended academic tutoring. The Levene's test of error variances was statistically significant, $\mathrm{F}(1,93)=17.35$, MSE $=271.44$, $\eta^{2}=.01, \mathrm{p}=.001$, suggesting that the assumption of homogeneity of variance was not met.

One sample Shapiro-Wilk test revealed that final grades of students who attended peer tutoring compared to those who attended academic tutoring was normally distributed. The Shapiro-Wilk value was $0.94(p=.052, N=39)$ for academic tutoring and the Shapiro-Wilk value was $0.94(p=56, N=56)$ for peer tutoring. The Shapiro-Wilk tests were statistically significant $(p<.05)$ for academic and peer tutoring. The null hypothesis there is no relationship between tutoring conditions (peer versus academic) and final grade earned in course of high risk/underprepared students cannot be rejected. Means and standard deviation for peer tutoring versus academic tutoring are presented in Table 1. 
Table 1ANOVA Results one-to-one tutoring versus group tutoring

\begin{tabular}{|l|l|l|l|ll|}
\hline Source & $d f$ & $S S$ & $M S$ & $F$ & $n^{2}$ \\
\hline Between Groups & 1 & 4711.5 & 4711.5 & $17.35^{*}$ & .01 \\
\hline Within Groups & 93 & 25244.07 & 271.44 & & \\
\hline Total & 94 & 29955.50 & 55.00 & & \\
\hline
\end{tabular}

$* p<.001$, one-tailed.

\section{Discussion}

Analysis of final grades earned revealed a statistically significant difference between students who received tutoring from their peers compared to those who received tutoring from academic tutors. The results indicated that students who were tutored by their peers had better final grades compared to students tutored by academic tutors. These findings were consistent with earlier studies suggesting that students who are tutored by their peers have more confidence in their ability to master the material (Bobko, 1984). The data demonstrated that students who received tutoring from their peers had better final grades than those who received tutoring from academic tutors. Tutoring programs that employ tutors who are similar in some way such as age, grade, or academic level to the tutee will increase the efficacy of tutoring programs (Hock, Deshler, \&Schumaker, 1999). Further, students learn through social interactions of their peers (Vygotsky, 1962). Peer tutoring can be an important part of interaction because peers provide natural contexts for peer behaviors (Klavian and Block, 2008). Vygotsky (1962) proposed that children learn through such social interactions.

\section{Conclusion}

From a social change perspective, college leaders can develop tutoring programs that employee peers as well as professional tutors. Understanding the correlation between peer tutoring and student success may give opportunity for support or services to enhance student outcomes. Developing tutoring programs that utilize tutors that are similar in some way such as age, grade, or academic level to the tutee will increase the use of tutoring programs. Further, students learn through social interactions of their peers (Vygotsky, 1962).

\section{References}

Bobko, E. (1984). The effective use of undergraduates as tutors for college science students. Journal of Chemical Education, 14(1), 60-62. Retrieved from http://www.nsta.org/college/

Damon, W. \& Phelps, E. (1989). Critical distinctions among three approaches to peer education. International Journal of Educational Research. 13, 9-19.

Duran, D. \& Monereo, C. (2005). Styles and sequences of cooperative interaction in fixedand reciprocal peer tutoring. Learning and Instruction. 15, 179-199.

Gisbert, D. \& Font, C. (2008). The impact of peer tutoring on the improvement of linguistic competence, self-concept as a writer and pedagogical satisfaction. Sage Journals. 29, (4) 481-499.

Hock, M., Schumaker, J., Deshler, D. (1995). Training strategic tutors to enhance learner Independence. Journal of Developmental Education. 19(1), 18-26. Retrieved from http://ncde.appstate.edu/publications/researchdevelopmental-education-ride

Kalkowski, P. (1996). Peer and Cross Aged Tutoring. School Improvement Series. 18,1-29.

Kalvina, A., Block, M. (2008). The effect of peer tutoring on interaction behaviors in inclusive physical education. Adapted Physical Activity Quarterly. 25, 132-158.

Maxwell, M. (1990). Does Tutoring Help? A Look at the Literature. Research in Developmental Education, 7(4), 3-8. Retrieved from http://ncde.appstate.edu/publications/research-developmental-education-ride

Maxwell, M. (1997). Improving student-learning skills. From Access to Success: A Book of Readings on College Developmental Education and Learning Assistance Programs (pp. 3-7). Clearwater, FL: H\&H Publishers.

Miller, M. (2005). Using peer tutoring in the classroom: Applications for students with emotional/behavioral disorders. Beyond Behaviors, 15 (1) 25-30.

Rheinheimer, D., Odeleye, B., Francois, G., \&Kusorgbor, C. (2012). Tutoring: A support strategy for at risk students. Learning Assistance Review, 15 (1) 23-24.

Thompson, B. \& Geren, P. (2002). Classroom strategies for identifying and helping college students at-risk for academic failure. College Student Journal, 36(3), 398-405. Retrieved from https://www.press.jhu.edu/journals/journal_of_college_student_development/

Vygotsky, L. S. (1962). Thought and language. Cambridge, MA: MIT press.

Vygotsky, L. S. (1978). Mind in society: The development of higher psychological process. (M. Cole, V. Steiner, S. Scribner \& E. Souberman, Eds. and Trans.). Cambridge, MA: Harvard University Press. 